\title{
Enhancing soil water holding capacity and provision of a potassium source via optimization of the pyrolysis of bamboo biochar
}

\author{
Tran Thi Thu Hien ${ }^{1,2,4} \oplus \cdot$ Toshiki Tsubota $^{3} \cdot$ Tomoyuki Taniguchi $^{1,4} \cdot$ Yoshiyuki Shinogi ${ }^{1,4}$
}

Received: 16 June 2020 / Accepted: 5 October 2020 / Published online: 20 October 2020

(c) The Author(s) 2020, corrected publication 2020

\begin{abstract}
Rapid expansion of cultivated bamboo negatively impacts on biodiversity and soil microbial community. As such, it is important to properly manage and use bamboo to prevent and control such issues. This study focuses on optimizing pyrolysis conditions to produce bamboo biochar for agricultural soil amendment, particularly soil potassium $(\mathrm{K})$ and water holding capacity. Bamboo chips were pyrolyzed under nitrogen gas at 400,600 , and $800{ }^{\circ} \mathrm{C}$ for 1 and $2 \mathrm{~h}$ of retention. A total of six biochar products were created: $400-1$ (i.e., $400{ }^{\circ} \mathrm{C}$ in $1 \mathrm{~h}$ ), 400-2, 600-1, 600-2, 800-1, and 800-2. The $600{ }^{\circ} \mathrm{C}$ bamboo biochar products were observed to have the greatest potential in increasing soil $\mathrm{K}$ and water holding capacity. The 600-1 product had the highest potassium content (4.87\%), with a water holding capacity of $3.73 \mathrm{~g} \mathrm{~g}^{-1}$, while the $600-2$ product had the second-highest potassium content (4.13\%) and the highest water holding capacity $\left(4.21 \mathrm{~g} \mathrm{~g}^{-1}\right)$ and cation exchange capacity. The $\mathrm{K}$ release in $600{ }^{\circ} \mathrm{C}$ products was larger and slower than that of the $400{ }^{\circ} \mathrm{C}$ and $800{ }^{\circ} \mathrm{C}$ products, respectively. The results also indicated that the physicochemical characteristics of bamboo biochar, such as yield, $\mathrm{pH}$, surface area, water holding capacity, and K content, were significantly impacted by temperature, retention time, or a combination of these parameters. The outcomes from this study are a valuable reference for bamboo biochar production targeting agricultural soil amendment, particularly when it is directed at increasing soil $\mathrm{K}$ and water holding capacity.
\end{abstract}

Keywords Bamboo biochar $\cdot$ Temperature $\cdot$ Retention time $\cdot$ Potassium $\cdot$ Water holding capacity $\cdot$ Cation exchange capacity

\section{Introduction}

Biochar may be considered a material that contributes to improving environmental sustainability by reducing nutrient leaching, decreasing greenhouse gas emissions, sequestering carbon, increasing soil fertility, and reducing heavy metal contamination in water and soil.

The effect of biochar on soil nutrient leaching and greenhouse gas emissions has been found to be dependent on its

Tran Thi Thu Hien

tranhien.asincv@gmail.com

1 Laboratory of Irrigation and Water Management, Faculty of Agriculture, Kyushu University, Fukuoka 8130395, Japan

2 Agricultural Science Institute of Northern Central Vietnam, Vietnam Academy of Agricultural Sciences, Vinh, Nghe An 44000, Vietnam

3 Department of Materials Science, Faculty of Engineering, Kyushu Institute of Technology, Kitakyushu 8048550, Japan

4 West No. 5 Building, 744 Motooka, Nishi-Ward, Fukuoka 8190395, Japan characteristics, soil properties, and the local climatic conditions. Clough et al. (2013) verified the diverse relationships between the type of biochar, the soil type, and nitrogen $(\mathrm{N})$ dynamics (including nutrient leaching and greenhouse gas emissions). Ventura et al. (2013) indicated that the addition of biochar significantly decreased short-term nitrate $\left(\mathrm{NO}_{3}{ }^{-}\right)$leaching from the surface layer of a sub-alkaline soil under temperate climatic conditions. Kameyama et al. (2012) found that although $\mathrm{NO}_{3}{ }^{-}$was weakly sorbed by the biochar surface, sorption increased with pyrolysis temperature due to the formation of base functional groups. Liu et al. (2019) concluded that biochar significantly reduced greenhouse gas emissions by $29 \%$ and $41 \%$ in paddy fields and dryland, respectively. The beneficial effect of biochar on soil fertility and its stability against degradation appears to be heavily dependent on the interactions between biochar, soil, and climatic conditions (Mimmo et al. 2014).

Bamboo is a potential feedstock for biochar production that is widely cultivated in the Asia-Pacific region, particularly Japan. Globally, the area cultivated with bamboo in tropical, subtropical, and temperate regions is approximately 
36.8 million ha (Lobovikov et al. 2007). Approximately, 10 million farmers cultivate bamboo, while there are 35 million jobs associated with this feedstock globally (Hogarth and Belcher 2013). Bamboo is a versatile crop, and all parts of the plant can be used in various industries such as in cosmetics, pigments, and medicines, or multiple purposes such as chopsticks, mats, craft, plywood, and food. However, the rapid growth of bamboo forests has been dwarfing other plant species; this has led to monoculture forests, contributing to the loss of biodiversity and soil nutrition, and damaging soil physical structure (Buckingham et al. 2011).

Experimental research has highlighted the potential for bamboo biochar to increase soil available potassium (K) and $\mathrm{K}$ uptake by crops (Wang et al. 2018a, b), total soil $\mathrm{K}$ (Wang et al. 2018a, b), and plant-available water in the soil (Hien et al. 2017). Bamboo biochar application has also been found to increase soybean nodules (Wang et al. 2018a, b) and the total sugar content of tomato fruits (Suthar et al. 2018). These bamboo biochars were pyrolyzed at different temperatures $\left(450-500{ }^{\circ} \mathrm{C}\right.$ ) and contained a $\mathrm{K}$ content of approximately 1.0-2.6\%. However, analytical research on the optimal pyrolysis conditions for bamboo biochar to maximize $\mathrm{K}$ content, $\mathrm{K}$ release, and water holding capacity is currently lacking.

Published studies have observed changes in the physicochemical properties of bamboo biochar with variations in temperature and have assessed its ability to adsorb heavy metals (Ye et al. 2015) or $\mathrm{NO}_{3}{ }^{-}-\mathrm{N}$ (Kameyama et al. 2017). Kameyama et al. (2017) also reviewed the potential for bamboo biochar to enhance the retention of soil water and nutrients although they did not provide the detailed data in this study.

This study aimed to grasp a detailed understanding of four key aspects: (1) the K content, (2) K release, (3) the water holding capacity of different bamboo biochars, and (4) the impact of temperature and retention time on the physicochemical properties of bamboo biochar. The results from this study will provide a necessary knowledge base for future research on the utilization of bamboo biochar for agricultural soil, in efforts to improve soil $\mathrm{K}$ content, soil water holding capacity, and crop productivity.

\section{Materials and methods}

\subsection{Biochar production}

Bamboo chips (B) that were of $20-40 \mathrm{~mm}$ in size were placed in a commercial tubular electric furnace (Advantec KT-1153, Advantec Toyo Kaisha, Ltd.) and heated with $\mathrm{N}_{2}$ gas flow. The pyrolysis conditions were adjusted to three different temperatures (i.e., 400, 600, and $800{ }^{\circ} \mathrm{C}$ ) and two retention times (i.e., 1 and $2 \mathrm{~h}$ ).

\subsection{Biochar analysis}

To analyze the physicochemical characteristics of the bamboo biochar, the biochar was ground and sieved to a size of less than $2 \mathrm{~mm}$ in diameter. The treated biochars were then used in a number of analyses.

\subsubsection{Yield, $\mathrm{pH}$, and electrical conductivity}

Biochar yield was calculated as the proportion of the biochar weight to the original material weight. The $\mathrm{pH}$ and electrical conductivity (EC) were determined according to the Japanese Industrial Standard (JIS) K 1474. Briefly, $1 \mathrm{~g}$ of powdered biochar was boiled with $100 \mathrm{~mL}$ of distilled water for $5 \mathrm{~min}$. After cooling to room temperature, another $100 \mathrm{~mL}$ of distilled water was added, and the mixture was filtered through filter paper (110 mm, Advantec Toyo Kaisha, Ltd.). Finally, a pH meter (HM-20, Horiba Co., Ltd.) and a conductivity meter (ES-14, Horiba Co., Ltd.) were used to measure the $\mathrm{pH}$ and EC of the filtrate solution.

\subsubsection{Ash and volatile matter content}

The ash content (\%) was calculated according to JIS M 8812 . Briefly, $1 \mathrm{~g}$ of dry biochar was placed into a commercial tubular electric furnace (Advantec KT-1153, Advantec Toyo Kaisha, Ltd.), and the temperature was adjusted to $500{ }^{\circ} \mathrm{C}$ for approximately $60 \mathrm{~min}$ and then increased to $815^{\circ} \mathrm{C}$ for a further $3 \mathrm{~h}$. Then, the remaining product was weighed on a scale to the nearest $0.1 \mathrm{mg}$. The ash content was determined as the percentage weight of the collected solid to the weight of the initial material.

Volatile matter (VM) was measured based on JIS M 8812, where the VM was calculated by recording the weight loss after heating $1 \mathrm{~g}$ of sample at $900{ }^{\circ} \mathrm{C}$ for $7 \mathrm{~min}$.

\subsubsection{Cation exchange capacity}

First, the exchangeable cation of biochar $(1.00 \pm 0.05 \mathrm{~g})$ was extracted by $1 \mathrm{M}(90 \mathrm{~mL})$ ammonium acetate aqueous solution, followed by $15 \mathrm{~h}$ of shaking and filtration. Then, the pellet was washed with $80 \%$ ethanol three times $(30 \mathrm{~mL})$ to remove the excess ammonium acetate. Ammonium was extracted with a $2 \mathrm{M}$ potassium chloride aqueous solution $(90 \mathrm{~mL})$, and the ammonium ion content was determined as the cation exchange capacity (CEC) through indophenol blue absorptiometry using a flow injection analyzer (AQLA-700-NO, Aqua Lab, Japan) (Nurudin et al. 2013). 


\subsubsection{Elemental and nutrient components}

The carbon $(\mathrm{C})$, hydrogen $(\mathrm{H})$, and $\mathrm{N}$ content were measured using a CHN corder (MT-5, Yanaco), while the oxygen (O) content was calculated as the difference $(100 \%-\mathrm{C}, \mathrm{H}, \mathrm{N}, \mathrm{S}$, ash \%) (Mimmo et al. 2014).

The other chemical components of the biochar, including phosphorus $(\mathrm{P})$ and $\mathrm{K}$, were measured using an energydispersive X-ray fluorescence spectrometer (EDX-RF; Shimadzu EDX-7000). The elemental quantitation was conducted using the fundamental parameter (FP) method (JP No. 03921872, DE No. 60042990. 3-08, GB No. 1054254 , US No. 6314158). This method uses theoretical intensity calculations to determine elemental composition from measured intensities; it is a powerful tool for the quantitative analysis of unknown samples. A balanced setting was required to use the FP method on the principal components of $\mathrm{C}, \mathrm{H}, \mathrm{N}$, and $\mathrm{O}$; the software automatically sets this balance.

\subsubsection{Surface characteristics}

The surface morphology of the bamboo biochar was observed using scanning electron microscopy (SEM; SU3500, Hitachi Co., Ltd.). The specific surface area was determined using $\mathrm{N}_{2}$ sorption isotherms run on an automated surface area and the application of the Brunauer-Emmett-Teller (BET) and $t$ plot analysis software available with the BELSORP mini II (Microtrac BEL) instrument.

\subsubsection{Water holding capacity}

Biochar samples $(50 \mathrm{~g})$ were shaken with distilled water for $2 \mathrm{~h}$ such that the pores were fully saturated. They were then filtered through a $110 \mathrm{~mm}$ filter paper and placed in a funnel to drain for $2 \mathrm{~h}$. The water holding capacity was determined as the mass of water retained per mass of dry soil or biochar (Mimmo et al. 2014).

\subsubsection{Release of potassium}

Biochar samples $(500 \mathrm{mg}$ ) were mixed with $50 \mathrm{~mL}$ of deionized (DI) water and transferred into a $100 \mathrm{~mL}$ polyethylene plastic flask. Samples were agitated for $15 \mathrm{~min}$, followed by centrifugation and decantation. This procedure was carried out in triplicate, and decanted solutions were analyzed to identify the "freely soluble K" fraction. To determine the slower release or encapsulated $\mathrm{K}$, the remaining materials were re-mixed with $50 \mathrm{~mL}$ of DI water, horizontally shaken (15 min), and then kept standing in the incubator at $25^{\circ} \mathrm{C}$. From these suspensions, the $\mathrm{pH}$ and $\mathrm{EC}$ of the soluble $\mathrm{K}$ were also measured. Following the first measurement day, subsamples were taken on days $2,3,4,5,7$, and 10 , and this extraction procedure was repeated in triplicate for each sample. The supernatants were passed through a $0.45 \mu \mathrm{m}$ poresize cellulose acetate filter, and soluble $\mathrm{K}$ was determined using a Horiba K meter (Nguyen et al. 2020).

\subsection{Statistical analysis}

Data from this experiment were analyzed using Microsoft Excel. A two-way analysis of variance (ANOVA) was conducted using IRRISTAT 4.0. Means were tested using the multiple comparisons using the least significant difference (LSD) method at $p<0.05$.

\section{Results}

\subsection{Basic characteristics of different types of bamboo biochar}

Figure 1 presents the yield, VM content, and ash content of bamboo biochars produced under different pyrolysis conditions (i.e., varying temperature and retention times). While the temperature, retention time, and the various combination of these parameters (temperature $\times$ retention time) significantly affected the yield and VM of biochar, the ash content was not significantly affected by retention time.

Multiple comparisons between treatments indicated that the biochar yield decreased in descending order of $400-1>400-2>600-1$ (39.9\%, 33.2\%, and $23.2 \%$, respectively), becoming almost stable at 600-1, 600-2, 800-1, and $800-2(23.2 \%, 23.2 \%, 22.1 \%$, and $21.5 \%$, respectively). Additionally, the VM and ash content showed different trends with an increase in temperature and retention time; the VM was observed to significantly decrease in descending order of 400-1 $>400-2>600-1$, while the ash content increased in the same order. The ash content was the highest for the 600-1 product and was found to be significantly higher than those of the $600-2,800-1$, and $800-2$ products.

\subsection{Chemical components of bamboo biochar}

\subsubsection{Chemical properties}

The $\mathrm{pH}$ of all bamboo biochars was alkaline, and temperature and retention time significantly affected the $\mathrm{pH}$ and $\mathrm{EC}$ of the biochar. The $\mathrm{pH}$ measurements showed a significant increase in ascending order of 400-1<800-1<800-2, while the EC of biochar increased in ascending order of $400-1<400-2<600-1$. Two possible reasons for such results are the reduction of acid functional groups on the surface and an increase in the ash content of biochar at higher temperatures (Fig. 2a, b). 


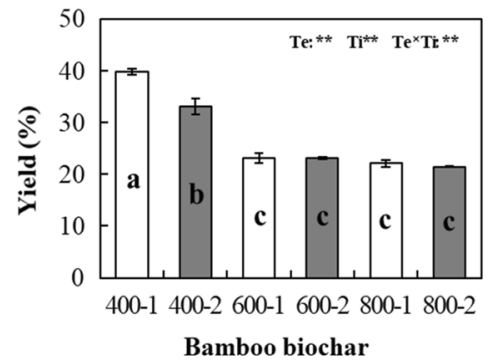

(a)

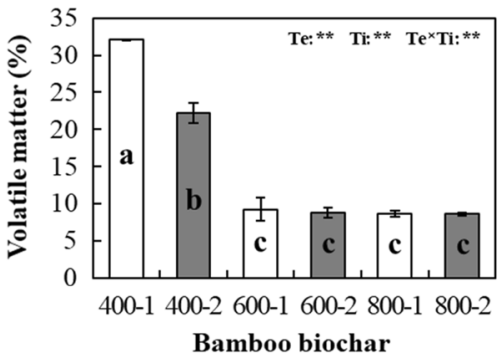

(b)

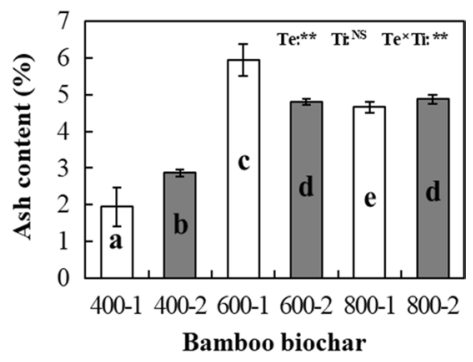

(c)
Fig. 1 a Yield; b volatile matter; and $\mathbf{c}$ ash content of bamboo biochar. Error bars indicate the standard deviations of means $(n=3) . T e$ temperature, $T i$ retention time, $T e^{\times} T i$ the combination of temperature and retention time. Asterisks (**) indicates a significant difference at $p<0.01$, and NS indicates that the difference is not significant. In the column, the different lowercase letters indicate the least significant difference (LSD) of treatments at LSD 0.05

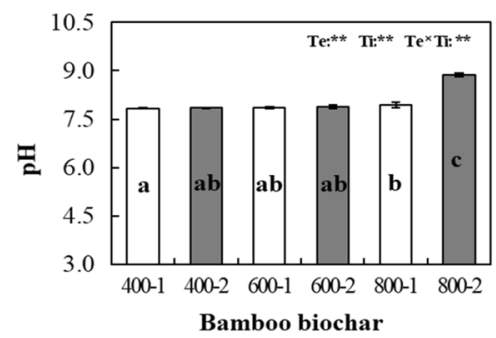

(a)

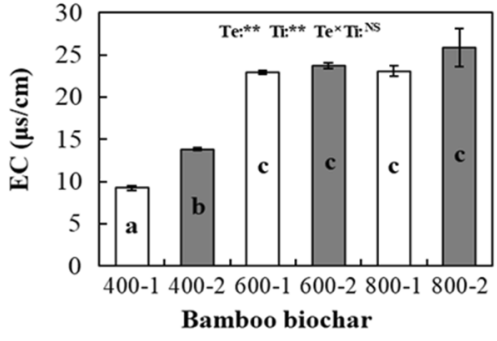

(b)

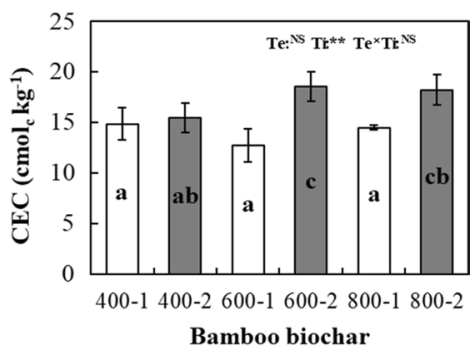

(c)
Fig. 2 a pH; b electrical conductivity; c cation exchange capacity. Error bars indicate the standard deviations of means $(n=3)$. Te temperature, $T i$ retention time, $T e^{\times} T i$ the combination of temperature and retention time. Asterisks (**) indicates a significant difference at

Retention time was the only parameter that had a significant impact on the CEC of the biochar. Multiple comparisons highlighted significant increase in CEC because of the retention time at 600 and $800{ }^{\circ} \mathrm{C}$. These CEC changes were a result of the physical and chemical properties of biochar, such as the number of acid functional groups and the negative surface charge area. The 600-2 produced had the highest CEC value (Fig. 2c).

\subsubsection{CHO elements}

The $\mathrm{H}$ and $\mathrm{O}$ content were found to decrease with increasing temperature, but they were stable with retention time. The $H$ content showed significant reduction with an increase in temperature from $400{ }^{\circ} \mathrm{C}$ to $800{ }^{\circ} \mathrm{C}$, while the $\mathrm{O}$ content had significantly reduced in descending order of 400-1 > 400-2 > 600-1. The reduction of $\mathrm{H}$ and $\mathrm{O}$ content indicated the volatility of $\mathrm{H}$ and $\mathrm{O}$ compounds within bamboo material under different pyrolysis conditions. In contrast, the $\mathrm{C}$ content had increased with temperature. The $\mathrm{C}$ in bamboo biochar varied in the range of 74-82\%; this shows $p<0.01$, and NS indicates that the difference is not significant. In the column, the different lowercase letters indicate the least significant difference (LSD) of treatments at LSD 0.05

that the application of bamboo biochar to farmlands is able to sequester large amounts of carbon (Fig. 3).

Further detail on the $\mathrm{H} / \mathrm{C}$ and $\mathrm{O} / \mathrm{C}$ atomic ratios is required to understand the aromaticity and polarity of biochar (Wang et al. 2015). Figure 4 illustrates a sharp reduction in the $\mathrm{H} / \mathrm{C}$ and $\mathrm{O} / \mathrm{C}$ ratios with an increase in temperature. The retention time was observed to have a slight effect on the $\mathrm{H} / \mathrm{C}$ and $\mathrm{O} / \mathrm{C}$ ratios, with the exception of the $\mathrm{O} / \mathrm{C}$ ratios of the $400{ }^{\circ} \mathrm{C}$ products. These results indicate that bamboo biochars became more aromatic and with reduced polarity with an increased in pyrolytic temperatures.

\subsubsection{Macronutrients}

Figure 5 shows the chemical elements present in the bamboo biochar and their respective quantities, while Fig. 6 presents the macronutrient content. The results indicate that the $\mathrm{N}$ and $\mathrm{P}$ content were much lower than the $\mathrm{K}$ content.

In bamboo biochar, $\mathrm{K}$ accounted for approximately $78-84 \%$ of the total ash content, and the $\mathrm{K}$ content varied with the pyrolysis conditions. The results indicate that $\mathrm{K}$ content in bamboo biochar was significantly affected by 


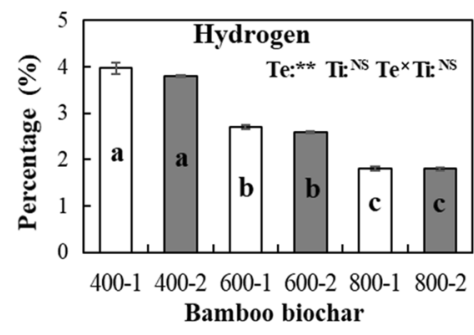

(a)

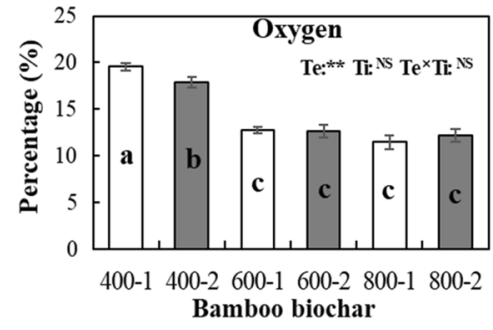

(b)

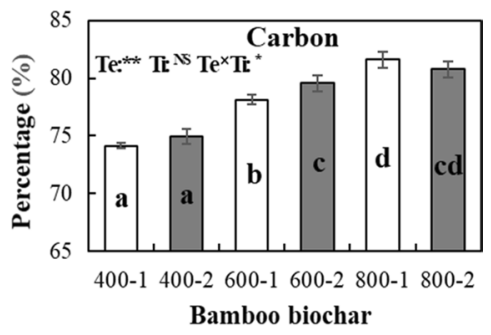

(c)
Fig. 3 a Percentage of hydrogen; $\mathbf{b}$ percentage of oxygen; $\mathbf{c}$ percentage of carbon. Error bars indicate the standard deviations of means $(n=3)$. $T e$ temperature, $T i$ retention time, $T e^{\times} T i$ the combination of temperature and retention time. Asterisks $(* *$ and $*$ ) indicate the sig- nificant differences at $p<0.01$ and $p<0.05$, respectively. NS indicates that the difference is not significant. In the column, the different lowercase letters indicate the least significant difference (LSD) of treatments at LSD 0.05

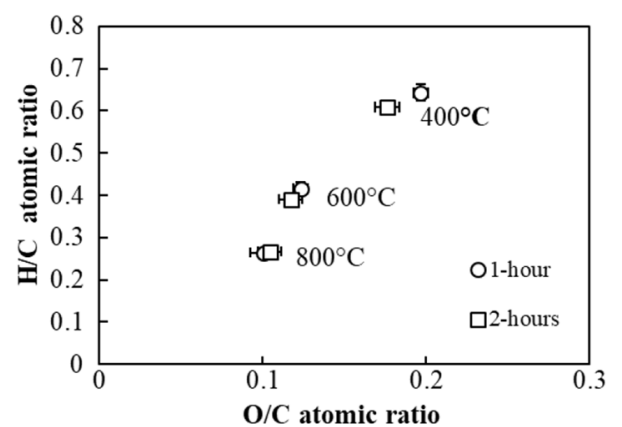

Fig. 4 Van Krevelen plot of elemental ratios for bamboo biochar produced at different pyrolysis conditions. Individual points are averages $(n=3)$, and error bars are standard deviations both pyrolysis temperature and retention time. At low temperatures $\left(400^{\circ} \mathrm{C}\right)$, extended retention times from $1 \mathrm{~h}$ to $2 \mathrm{~h}$ resulted in a significant increase in $\mathrm{K}$ content from $1.51 \%$ to $2.39 \%$. With an increase in temperature from $400{ }^{\circ} \mathrm{C}$ to $600{ }^{\circ} \mathrm{C}$, the highest $\mathrm{K}$ content was attained for the $600-1$ product $(4.87 \%)$, with a slight reduction for $600-2(4.13 \%)$. The K content of the $800-1$ product was significantly lower than that of the 600-2 product; however, no difference in $\mathrm{K}$ content was found for 600-2 and 800-2.

\subsection{BET surface area and SEM morphology}

$\mathrm{N}$ gas absorption was used to estimate the BET specific surface area (SSA) and total pore volume (TPV). Analytical results indicated that temperature, retention time, and various combinations of these parameters significantly increased the SSA and TPV of bamboo biochar (Fig. 7).
Fig. 5 X-ray fluorescence diagrams of bamboo biochar at different pyrolysis conditions
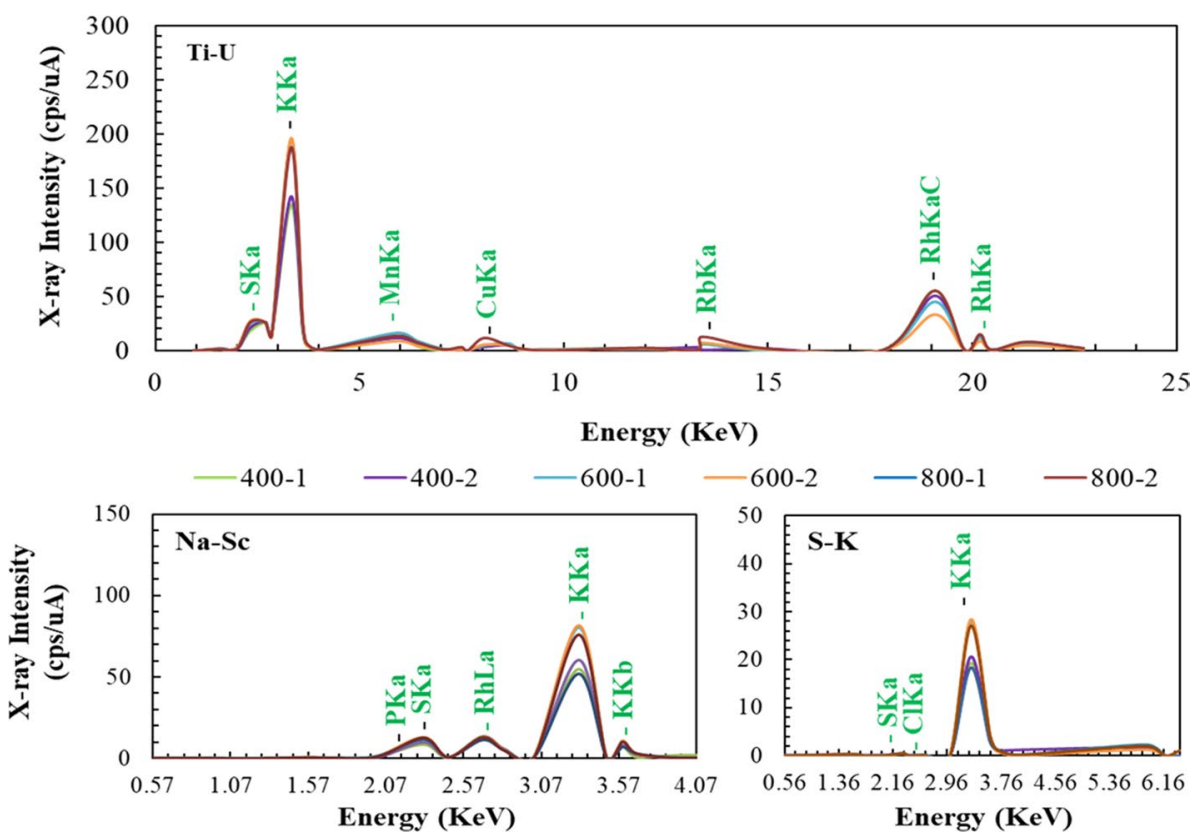


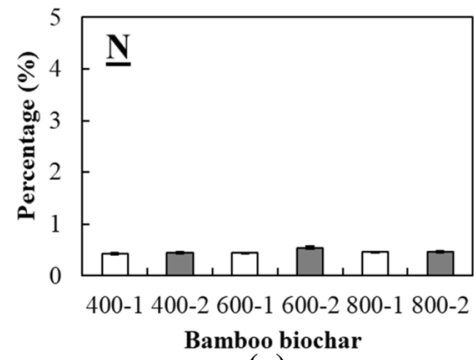

(a)

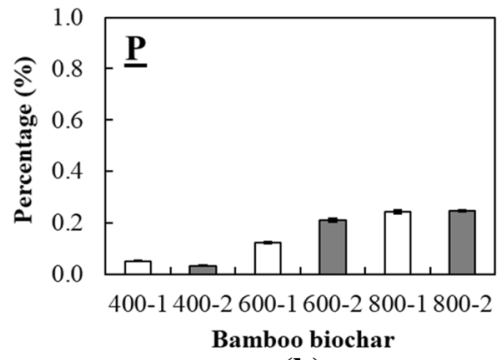

(b)

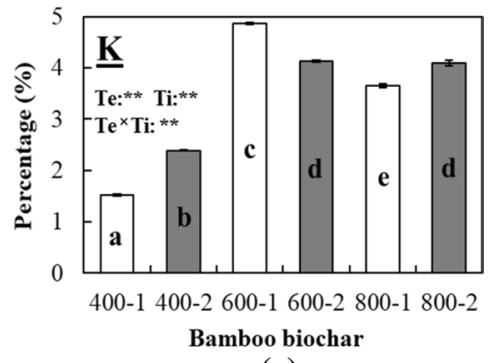

(c)
Fig. 6 a Percentage of nitrogen; $\mathbf{b}$ percentage of phosphorus; $\mathbf{c}$ percentage of potassium. Error bars indicate the standard deviations of means $(n=3)$. $T e$ temperature, $T i$ retention time, $T e^{\times} T i$ the combination of temperature and retention time. Asterisks (**) indicates a sig- nificant difference at $p<0.01$. In the column, the different lowercase letters indicate the least significant difference (LSD) of treatments at LSD 0.05
Fig. 7 a BET specific surface area; $\mathbf{b}$ total pore volume. Error bars indicate the standard deviations of means $(n=3)$. $T e$ temperature, $T i$ retention time, $T e^{\times} T i$ the combination of temperature and retention time. Asterisks $(* *)$ indicates a significant difference at $p<0.01$. In the column, the different lowercase letters indicate the least significant difference (LSD) of treatments at LSD 0.05

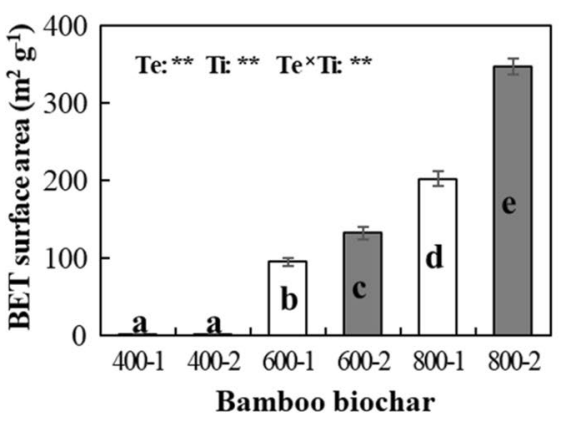

(a)

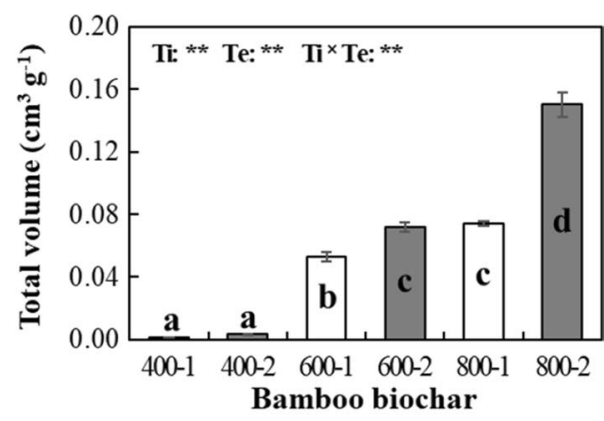

(b)
Figure 8 presents the SEM imagery with different magnifications of bamboo biochars; high-resolution images indicated a smoother surface for the 600-2, 800-1, and 800-2 products compared with the 400-1, 400-2, and 600-1 products. This phenomenon may be attributed to the volatilization of compounds because of the high temperatures and retention times.

\subsection{Water holding capacity of biochars}

Biochar water holding capacity varied according to the pyrolysis conditions (Fig. 9). At $400{ }^{\circ} \mathrm{C}$, there was no difference in the water holding capacity between $1 \mathrm{~h}$ and $2 \mathrm{~h}$ of heating. However, the water holding capacity significantly increased in ascending order of 400-2 $<600-1<600-2$. The water holding capacity reduced from $4.21 \mathrm{~g} \mathrm{~g}^{-1}(600-2$, the largest) to $3.22 \mathrm{~g} \mathrm{~g}^{-1}$ (800-1, the lowest) and increased again to $3.85 \mathrm{~g} \mathrm{~g}^{-1}$ with $800-2$. The changes in physicochemical properties of the biochar, such as SSA, TPV, and CEC, created a change in the water holding capacity of all six types of bamboo biochars.

\subsection{Release of K}

The amount of $\mathrm{K}$ released in the DI water of bamboo biochar varied depending on the pyrolysis conditions (Fig. 10); the
$\mathrm{K}$ content increased with temperature and retention time (at 600 and $800^{\circ} \mathrm{C}$ ), while the experimental duration was also observed to increase the amount of $\mathrm{K}$ released. The amount of soluble $\mathrm{K}$ on the first day of the experiment was much larger than that of the subsequent 9 days, particularly for the $800{ }^{\circ} \mathrm{C}$ biochar products. The $600{ }^{\circ} \mathrm{C}$ biochar products contained the largest cumulative soluble $\mathrm{K}$ from the second to tenth day of the release experiment. These results indicate that the $\mathrm{K}$ content in the $600^{\circ} \mathrm{C}$ biochar products may have been released at a more gradual rate than the $\mathrm{K}$ content in the other biochar products.

\section{Discussion}

\subsection{Improved basic soil conditions}

Bamboo biochars were characterized as alkaline with high porosity (especially for the 600 and $800{ }^{\circ} \mathrm{C}$ products). As such, the application of bamboo biochar was expected to improve several aspects of agricultural soil, including the bacterial community and soil nutrient content, especially in acidic soils.

Soil $\mathrm{pH}$ is one of the factors governing soil microbial abundance and activity (Aciego Pietri and Brookes 2008; Lehmann et al. 2011). However, fungal and bacterial 


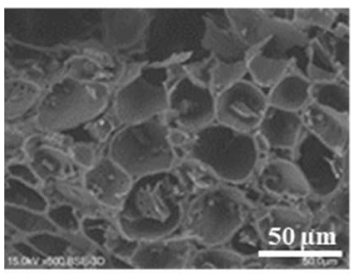

400-1

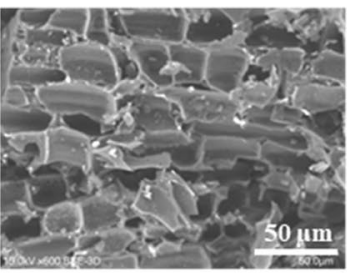

600-1

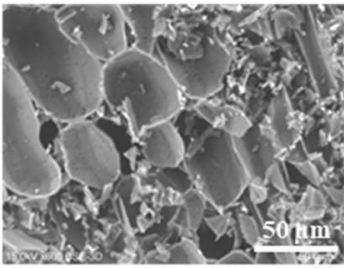

800-1

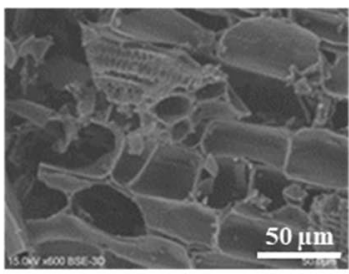

400-2

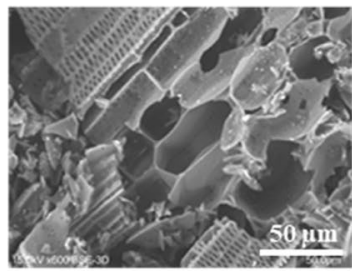

600-2

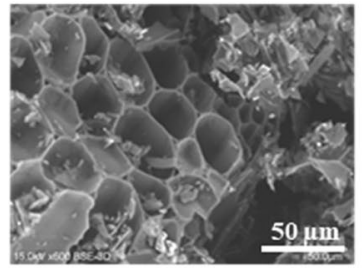

800-2

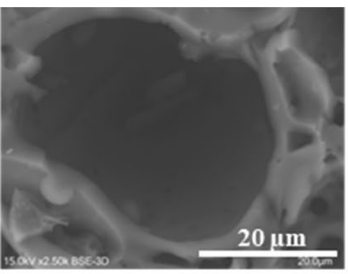

400-1

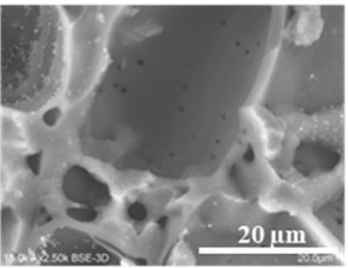

600-1

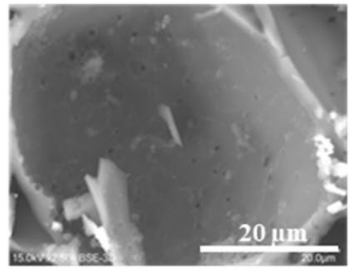

800-1

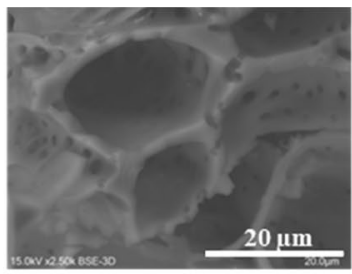

400-2

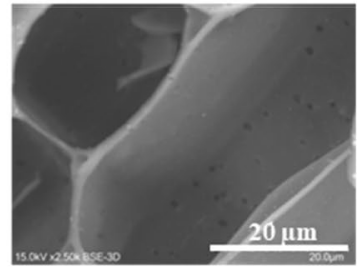

$600-2$

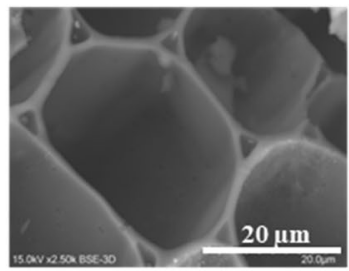

800-2

Fig. 8 SEM imagery of bamboo biochar at two resolutions of 600 and 2500 times

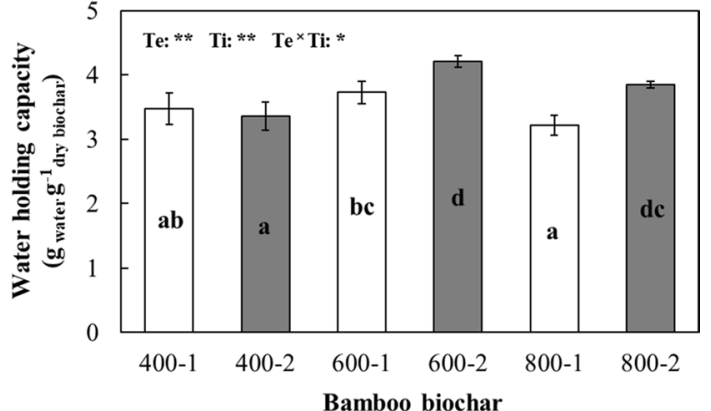

Fig. 9 Water holding capacity of bamboo biochar. Error bars indicate the standard deviations of means $(n=3)$. Te temperature, Ti retention time, $\mathrm{Te}{ }^{\times} \mathrm{Ti}$ the combination of temperature and retention time. Asterisks $(* *$ and $*$ ) indicate a significant difference at $p<0.01$ and $p<0.05$, respectively. In the column, the different lowercase letters indicate the least significant difference (LSD) of treatments at LSD 0.05

populations react differently to changes in $\mathrm{pH}$; increasing soil $\mathrm{pH}$ up to $\sim 7$ had been found to increase bacterial abundance, while there was no change in the total fungal biomass with this pH increase (Rousk et al. 2010). As the bamboo biochars were alkaline, their application in acidic soil is likely to increase soil $\mathrm{pH}$, thus supporting the growth of soil microbial communities. Moreover, biochars provide favorable habitat for soil microbes by increasing soil

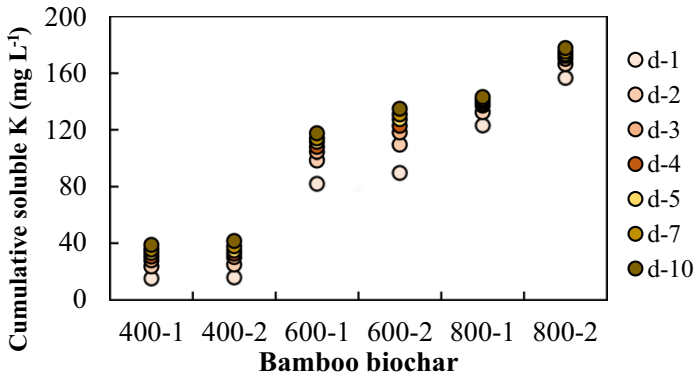

Fig. 10 Cumulative soluble $\mathrm{K}$ for the different types of bamboo biochar products

porosity, nutrient content, and water retention (Ahmad et al. 2014; Jaafar et al. 2014, 2015; Mohamed et al. 2016; Ye et al. 2017).

In acidic soils, high concentrations of aluminum ( $\mathrm{Al})$, iron $(\mathrm{Fe})$, and manganese $(\mathrm{Mn})$ were observed. These soluble compounds combined with $\mathrm{P}$ to create insoluble compounds and reduce the available $\mathrm{P}$ in the soil solution. With the application of bamboo biochar at $\mathrm{pH}>7$, the free $\mathrm{Fe}$, $\mathrm{Al}$, and $\mathrm{Mn}$ oxide concentrations had been reduced by transforming into hydroxide forms; this increased the soil equilibrium P solution. The application of biochars may also increase the ionic strength of the solution due to the release of soluble salt. This soluble salt may decrease the positive 
electric potential of the acidic soil surface through the screening effect, resulting in the reduction of soil P sorption (Dume et al. 2017). To strengthen this conclusion, Glaser and Lehr (2019) found that biochar application had significantly increased plant-P availability with $95 \%$ confidence for an acidic to neutral soil $(\mathrm{pH} \leq 7.5)$, and observed that this enhancement was able to be sustained for at least 5 years.

\subsection{Increase in water holding capacity}

The water holding capacity of bamboo biochar impacts the soil water regime. Biochar produced under different pyrolysis conditions had different physicochemical characteristics that affected the water holding capacity.

Physical absorption, determined by the porosity (including SSA and TPV), is considered an important factor in determining the water retention of biochar (Batista et al. 2018). Therefore, an increase in the water holding capacity in ascending order of 400-1 $<400-2<600-1<600-2$ may be attributed to the increase in the SSA and TPV of the biochar. Pores sized of $0.5-50 \mu \mathrm{m}$ have been identified as being able to retain water and nutrients for some plants (Batista et al. 2018). The bamboo biochars in our study contained a large number of $0.5-50 \mu \mathrm{m}$ pores, as indicated by the SEM imagery (Fig. 8). These pores may be classified into two classes: fine-coarse pores $(10-50 \mu \mathrm{m})$ and medium-sized pores $(0.2-10 \mu \mathrm{m})$. The fine-coarse pores are ideal for water holding at field capacity, while the medium-sized pores are able to maintain a greater volume of plant-available water (Blume et al. 2016).

Chemical adsorption is considered as the second most influential parameter for water holding capacity of the biochar (Batista et al. 2018; Kizito et al. 2019). Between 600-2 and 800-1 products, 800-1 showed the significant increase in BET surface area, no difference in TPV (Fig. 7); however, the $\mathrm{H} / \mathrm{C}$ and $\mathrm{O} / \mathrm{C}$ ratios showed the large reduction (Fig. 4). The changes in $\mathrm{H} / \mathrm{C}$ and $\mathrm{O} / \mathrm{C}$ ratios indicated that 800-1 became more aromatic and less polarity compared with those of 600-2 and resulted in the reduction of water holding capacity. In addition, 800-2 had the largest BET surface area, no difference in the $\mathrm{H} / \mathrm{C}$ and $\mathrm{O} / \mathrm{C}$ ratios compared to those of the 800-1; this reasoned for the increase in holding water of 800-1 to 800-2.

Bamboo biochar has greater potential for retaining water compared to other feedstocks such as rice husk and wood. In this study, the water holding capacity of bamboo char varied from 3.22 to $4.21 \mathrm{~g} \mathrm{~g}^{-1}$, while that of Miscanthus biochar, Cateenga, and Cashew wood biochars was 0.31-0.49, $0.61-2.64$, and $0.28-0.60 \mathrm{~g} \mathrm{~g}^{-1}$, respectively (Gondim et al. 2018; Mimmo et al. 2014). Bamboo biochar also increased the plant-available water in soil to a much greater extent than that of rice husk char (Hien et al. 2017). Among all produced bamboo biochars, the $600{ }^{\circ} \mathrm{C}$ products showed the greatest potential in terms of enhancing water holding capacity. At $600{ }^{\circ} \mathrm{C}$, extending the retention time from $1 \mathrm{~h}$ to $2 \mathrm{~h}$ created an increase in porosity (SSA, TPV), CEC, and ultimately resulted in better water holding biochar for the 600-2 product compared to its 600-1 counterpart.

\subsection{Increase in soil fertility}

Biochar application increased the $\mathrm{P}$ available for crop in acidic conditions by increasing soil $\mathrm{pH}$. The high CEC of biochar also highlights its potential to retain cations, including soil nutrients such as $\mathrm{K}^{+}, \mathrm{NH}_{4}^{+}$, and $\mathrm{Ca}^{2+}$. The CEC value varies with temperature, feedstocks (Kameyama et al. 2017), and retention times (Fig. 2c). Previous studies have found both the increase and decrease in biochar CEC with an increase in the pyrolysis temperature. The high CEC of biochar at a low temperature is related to the presence of oxygenated groups, while the CEC of biochar at high temperatures was mostly associated with a large negative surface charge area (Gomez-Eyles et al. 2013; Pariyar et al. 2020; Kameyama et al. 2017).

At 600 and $800{ }^{\circ} \mathrm{C}$, a retention time of $2 \mathrm{~h}$ could create larger SSA and TPV biochar products compared with those of the $1 \mathrm{~h}$ biochars; however, these products had the same $\mathrm{H} / \mathrm{C}$ and $\mathrm{O} / \mathrm{C}$ ratios. Therefore, the difference in the CEC of the 600 and $800{ }^{\circ} \mathrm{C}$ products may be related to their SSA and TPV. Among all bamboo biochar products, the 600-2 product had the highest CEC, demonstrating its potential in retaining soil nutrients. The SEM imagery of bamboo biochar showed the presence of $0.5-50 \mu \mathrm{m}$ pores that appear to be suitable to maintain the soil nutrient level (Batista et al. 2018). The application of biochar to low CEC soil may increase this value of the soil-biochar mixture. However, the degree of enhancement is dependent on the soil, biochar, and biochar dose (Chintala et al. 2014; Hailegnaw et al. 2019).

Macronutrients were also found in bamboo biochar; while $\mathrm{N}$ was known to be unavailable to crops (Kameyama et al. 2017), $P$ and $K$ were observed to be available for plant uptake as demonstrated by Zhang et al. (2016) and Amin (2016), respectively. The $\mathrm{P}$ content had been maintained at small quantities $(<0.4 \%)$, while there was a high $\mathrm{K}$ content $(1.51-4.87 \%)$. These results indicate that bamboo biochars may be a potential source of $\mathrm{K}$ for agricultural soils.

\subsection{Potassium source}

In crops, $\mathrm{K}$ is an indispensable element that aids in various functions, including photosynthesis, protein synthesis, and the activation of specific enzymes (Hopkins and Hüner 2008). During pyrolysis, the organic matter of $\mathrm{K}$ is decomposed even at low temperatures (van Lith et al. 2008). The remaining $\mathrm{K}$ in biochar may exist in three forms: (i) as incompletely decomposed organic matter (Feng et al. 2017); 
(ii) as free salts, such as $\mathrm{KCl}, \mathrm{KClO}_{4}$, and $\mathrm{K}_{2} \mathrm{SO}_{4}$ (van Lith et al. 2008); and (iii) in surface-sorbed or encapsulated $\mathrm{K}$ (Nguyen et al. 2020).

Different pyrolysis conditions may create biochars with different $\mathrm{K}$ contents. The increase in $\mathrm{K}$ content in ascending order of $400-1<400-2<600-1$ is a result of the volatilization of $\mathrm{H}, \mathrm{O}$, and $\mathrm{C}$ compounds at different temperatures. In contrast, the decrease in $\mathrm{K}$ in the ascending order of $600-1<600-2<800-1$ may be attributed to the melting of $\mathrm{K}$ compounds such as potassium perchlorate $\left(\mathrm{KClO}_{4}-610^{\circ} \mathrm{C}\right)$ and potassium chloride $\left(\mathrm{KCl}-773^{\circ} \mathrm{C}\right)($ Merck 2016, 2017). A high $\mathrm{K}$ content was observed in bamboo biochar, particular for the $600{ }^{\circ} \mathrm{C}$ products.

The release of $\mathrm{K}$ from bamboo biochar may contribute to enhanced soluble K concentrations in soil following biochar application. With heating, the $\mathrm{K}$ content in its different forms including salt- $\mathrm{K}$, encapsulated- $\mathrm{K}$, and remaining $\mathrm{K}$ organic compounds may become altered (Feng et al. 2017; Nguyen et al. 2020). In the structure of the lowest temperature biochar product $\left(400^{\circ} \mathrm{C}\right)$, the largest amount of organic matter was maintained equivalent to the highest content of $\mathrm{H}$ and $\mathrm{O}$ (Fig. 3). $\mathrm{K}$ in this organic matter could not solubilize; as such, only a small amount of $\mathrm{K}$ release was observed. In contrast, at a high temperature biochar product (i.e., $800^{\circ} \mathrm{C}$ ), a large amount of organic $\mathrm{C}-\mathrm{O}-\mathrm{K}$ compounds was broken and was then created the $\mathrm{K}$ salts; this prediction was demonstrated in the C, H, O (Fig. 3), and EC (Fig. 2) results. Therefore, a rapid and large release of $\mathrm{K}$ in the $800{ }^{\circ} \mathrm{C}$ biochar products corresponded to the formation of a large quantity of salts. When the $800{ }^{\circ} \mathrm{C}$ biochar products were in contact with water, the free $\mathrm{K}$ salts dissolved, resulting in the largest recorded soluble $\mathrm{K}$ on the first day of the experiment. Ultimately, the $600{ }^{\circ} \mathrm{C}$ biochar products contained the highest amount of total $\mathrm{K}$ and slow-release $\mathrm{K}$ compared with the other products. Nguyen et al. (2020) also found the highest amount of slow-release $\mathrm{K}$ at this temperature in fern char.

The results of $\mathrm{K}$ in bamboo biochar, particularly in $600{ }^{\circ} \mathrm{C}$ products, provide important data for future research on bamboo biochar, soil $\mathrm{K}$, and crop productivity.

\section{Conclusion}

The results from this study have indicated the potential for bamboo biochar as an agricultural soil amendment material. As this study was aimed at increasing the soil $\mathrm{K}$ content and water holding capacity, $600{ }^{\circ} \mathrm{C}$ was found to be the most appropriate pyrolysis temperature to achieve these aims. The release of $\mathrm{K}$ in the $600{ }^{\circ} \mathrm{C}$ products was slower than that of the other temperature biochars. The 600-1 product had the highest $\mathrm{K}$ content $(4.87 \%)$ and the second-highest water holding capacity. In contrast, the $600-2$ product was found to have the highest water holding capacity $\left(4.21 \mathrm{~g} \mathrm{~g}^{-1}\right)$ and CEC (18.52 cmolc kg-1), as well as the second-highest $\mathrm{K}$ content. All bamboo biochars shared certain characteristics such as alkalinity and high $\mathrm{K}$ and $\mathrm{C}$ content. We also observed that temperature, retention time, and the various combination of these parameters significantly impacted the physicochemical properties of the bamboo biochar, including yield, $\mathrm{pH}$, surface area, water holding capacity, and $\mathrm{K}$ content. To further explore the outcomes of this study, field research on the effects of $600{ }^{\circ} \mathrm{C}$ bamboo biochar application on soil $\mathrm{K}, \mathrm{K}$ uptake, and the growth, and yield of sugarcane is currently being conducted.

Acknowledgements We would like to thank Professor Shinjiro SATO and his students from the Faculty of Science and Engineering, Soka University, Japan, for helping us with the CEC measurement. Their support led us to explore the ability of bamboo biochar for soil amendment.

Funding Not applicable.

Data availability The data that support the finding of this study are available from the corresponding author upon the reasonable request.

Code availability The code that supports the finding of this study is available from the corresponding author upon the reasonable request.

\section{Compliance with ethical standards}

Conflict of interest The authors declare that they have no conflict of interests.

Open Access This article is licensed under a Creative Commons Attribution 4.0 International License, which permits use, sharing, adaptation, distribution and reproduction in any medium or format, as long as you give appropriate credit to the original author(s) and the source, provide a link to the Creative Commons licence, and indicate if changes were made. The images or other third party material in this article are included in the article's Creative Commons licence, unless indicated otherwise in a credit line to the material. If material is not included in the article's Creative Commons licence and your intended use is not permitted by statutory regulation or exceeds the permitted use, you will need to obtain permission directly from the copyright holder. To view a copy of this licence, visit http://creativecommons.org/licenses/by/4.0/.

\section{References}

Aciego Pietri JC, Brookes PC (2008) Relationships between soil pH and microbial properties in a UK arable soil. Soil Biol Biochem 40:1856-1861. https://doi.org/10.1016/j.soilbio.2008.03.020

Ahmad M, Rajapaksha AU, Lim JE, Zhang M, Bolan N, Mohan D, Vithanage M, Lee SS, Ok YS (2014) Biochar as a sorbent for contaminant management in soil and water: a review. Chemosphere 99:19-33. https://doi.org/10.1016/j.chemosphere.2013.10.071

Amin AE-EAZ (2016) Impact of corn cob biochar on potassium status and wheat growth in a calcareous sandy soil. Commun Soil Sci Plant Anal 47:2026-2033. https://doi.org/10.1080/00103 624.2016.1225081

Batista EMCC, Shultz J, Matos TTS, Fornari MR, Ferreira TM, Szpoganicz B, De Freitas RA, Mangrich AS (2018) Effect of 
surface and porosity of biochar on water holding capacity aiming indirectly at preservation of the Amazon biome. Sci Rep 8:1-9. https://doi.org/10.1038/s41598-018-28794-z

Blume H-P, Brümmer GW, Fleige H, Horn R, Kandeler E, KögelKnabner I, Kretzschmar R, Stahr K, Wilke B-M (2016) Physical properties and processes. Scheffer/schachtschabel soil science. Spinger, Berlin, pp 175-283. https://doi.org/10.2136/sssaj 2016.0002br

Buckingham K, Jepson P, Wu L, Rao IVR, Jiang S, Liese W, Lou Y, Fu M (2011) The potential of bamboo is constrained by outmoded policy frames. Ambio 40:544-548. https://doi.org/10.1007/s1328 0-011-0138-4

Chintala R, Mollinedo J, Schumacher TE, Malo DD, Julson JL (2014) Effect of biochar on chemical properties of acidic soil. Arch Agron Soil Sci 60:393-404. https://doi.org/10.1080/03650 340.2013.789870

Clough T, Condron L, Kammann C, Müller C (2013) A review of biochar and soil nitrogen dynamics. Agronomy 3:275-293. https ://doi.org/10.3390/agronomy3020275

Dume B, Tessema DA, Regassa A, Berecha G (2017) Effects of biochar on phosphorus sorption and desorption in acidic and calcareous soils. Civ Environ Res 9:10-20

Feng D, Zhao Y, Zhang Y, Zhang Z, Sun S (2017) Roles and fates of $\mathrm{K}$ and $\mathrm{Ca}$ species on biochar structure during in-situ $\operatorname{tar} \mathrm{H}_{2} \mathrm{O}$ reforming over nascent biochar. Int J Hydrog Energy 42:2168621696. https://doi.org/10.1016/j.ijhydene.2017.07.096

Glaser B, Lehr VI (2019) Biochar effects on phosphorus availability in agricultural soils: a meta-analysis. Sci Rep 9:1-9. https://doi. org/10.1038/s41598-019-45693-z

Gomez-Eyles JL, Beesley L, Moreno-Jimenez E, Ghosh U, Sizmur $\mathrm{T}$ (2013) The potential of biochar amendments to remediate contaminated soils. In: Ladygina N, Rineau F (eds) Biochar and soil biota. CRC Press, Boca Raton, pp 100-133. https://doi. org/10.13140/2.1.1074.9448

Gondim RS, Muniz CR, Lima CEP, Dos SCLA (2018) Explaining the water-holding capacity of biochar by scanning electron microscope images. Rev Caatinga 31:972-979. https://doi. org/10.1590/1983-21252018V31N420RC

Hailegnaw NS, Mercl F, Pračke K, Száková J, Tlustoš P (2019) Mutual relationships of biochar and soil $\mathrm{pH}$, CEC, and exchangeable base cations in a model laboratory experiment. J Soils Sediments 19:2405-2416. https://doi.org/10.1007/s1136 8-019-02264-Z

Hien TTT, Shinogi Y, Taniguchi T (2017) The different expressions of draft cherry tomato growth, yield, quality under bamboo and rice husk biochars application to clay loamy soil. Agric Sci 08:934-948. https://doi.org/10.4236/as.2017.89068

Hogarth NJ, Belcher B (2013) The contribution of bamboo to household income and rural livelihoods in a poor and mountainous county in Guangxi, China. Int For Rev 15:71-81. https://doi. org/10.1505/146554813805927237

Hopkins WG, Hüner NPA (2008) Introduction to plant physiology, 4th edn. John Wiley \& Sons, Hoboken

Jaafar NM, Clode PL, Abbott LK (2014) Microscopy observations of habitable space in biochar for colonization by fungal hyphae from soil. J Integr Agric 13:483-490. https://doi.org/10.1016/ S2095-3119(13)60703-0

Jaafar NM, Clode PL, Abbott LK (2015) Soil microbial responses to biochars varying in particle size, surface and pore properties. Pedosphere 25:770-780. https://doi.org/10.1016/S1002 $-0160(15) 30058-8$

Kameyama K, Miyamoto T, Shiono T, Shinogi Y (2012) Influence of sugarcane bagasse-derived biochar application on nitrate leaching in calcaric dark red soil. J Environ Qual 41:1131-1137. https://doi.org/10.2134/jeq2010.0453
Kameyama K, Iwata Y, Miyamoto T (2017) Biochar amendment of soils according to their physicochemical properties. Jpn Agric Res Q 51:117-127. https://doi.org/10.6090/jarq.51.117

Kizito S, Luo H, Lu J, Bah H, Dong R, Wu S (2019) Role of nutrientenriched biochar as a soil amendment during maize growth: exploring practical alternatives to recycle agricultural residuals and to reduce chemical fertilizer demand. Sustain. https://doi. org/10.3390/su11113211

Lehmann J, Rillig MC, Thies J, Masiello CA, Hockaday WC, Crowley D (2011) Biochar effects on soil biota - a review. Soil Biol Biochem 43:1812-1836. https://doi.org/10.1016/j.soilb io.2011.04.022

Liu X, Mao P, Li L, Ma J (2019) Impact of biochar application on yield-scaled greenhouse gas intensity: a meta-analysis. Sci Total Environ 656:969-976. https://doi.org/10.1016/j.scito tenv.2018.11.396

Lobovikov M, Paudel S, Piazza M, Ren H, Wu J (2007) Non-wood forest products: world bamboo resources. FAO, Viale delle Terme di Caracalla, 00153, Rome, Italy. https://doi.org/https:// doi.org/10.13140/RG.2.1.1042.3764

Merck (2016) Safety data sheet for potassium perchlorate. https:// www.merckmillipore.com/JP/en/product/Potassium-perchlorat e, MDA_CHEM-105076. Accessed 9 Mar 2020

Merck (2017) Safety data sheet for potassium chloride. https://www. merckmillipore.com/JP/en/product/msds/MDA_CHEM-10493 8. Accessed 9 Mar 2020

Mimmo T, Panzacchi P, Baratieri M, Davies CA, Tonon G (2014) Effect of pyrolysis temperature on miscanthus (Miscanthus $X$ giganteus) biochar physical, chemical and functional properties. Biomass Bioenergy 62:149-157. https://doi.org/10.1016/j. biombioe.2014.01.004

Mohamed BA, Ellis N, Kim CS, Bi X, Emam AER (2016) Engineered biochar from microwave-assisted catalytic pyrolysis of switchgrass for increasing water-holding capacity and fertility of sandy soil. Sci Total Environ 566-567:387-397. https://doi. org/10.1016/j.scitotenv.2016.04.169

Nguyen ATQ, Bui TA, Mai NT, Tran HT, Tran SV, Nguyen NH, Tsubota T, Shinogi Y, Dultz S, Nguyen MN (2020) Release kinetics of potassium from silica-rich fern-derived biochars. Agron J 112:1713-1725. https://doi.org/10.1002/agj2.20209

Nurudin M, Ohta S, Hardiyanto EB, Mendham D, Wicaksono A, Heriyanto J, Watanabe M (2013) Relationships between soil characteristics and productivity of Acacia mangium in South Sumatra. Tropics 22:1-12. https://doi.org/10.3759/tropics.22.1

Pariyar P, Kumari K, Jain MK, Jadhao PS (2020) Evaluation of change in biochar properties derived from different feedstock and pyrolysis temperature for environmental and agricultural application. Sci Total Environ 713:136433. https://doi. org/10.1016/j.scitotenv.2019.136433

Rousk J, Bååth E, Brookes PC, Lauber CL, Lozupone C, Caporaso JG, Knight R, Fierer N (2010) Soil bacterial and fungal communities across a pH gradient in an arable soil. Int Soc Microb Ecol J 4:1340-1351. https://doi.org/10.1038/ismej.2010.58

Suthar RG, Wang C, Nunes MCN, Chen J, Sargent SA, Bucklin RA, Gao B (2018) Bamboo biochar pyrolyzed at low temperature improves tomato plant growth and fruit quality. Agriculture 8:1-13. https://doi.org/10.3390/agriculture8100153

van Lith SC, Jensen PA, Frandsen FJ, Glarborg P (2008) Release to the gas phase of inorganic elements during wood combustion. Part 2: influence of fuel composition. Energy Fuels 22:15981609. https://doi.org/10.1021/ef060613i

Ventura M, Sorrenti G, Panzacchi P, George E, Tonon G (2013) Biochar reduces short-term nitrate leaching from a horizon in an apple orchard. J Environ Qual 42:76-82. https://doi. org/10.2134/jeq2012.0250 
Wang X, Zhou W, Liang G, Song D, Zhang X (2015) Characteristics of maize biochar with different pyrolysis temperatures and its effects on organic carbon, nitrogen and enzymatic activities after addition to fluvo-aquic soil. Sci Total Environ 538:137144. https://doi.org/10.1016/j.scitotenv.2015.08.026

Wang C, Alidoust D, Yang X, Isoda A (2018a) Effects of bamboo biochar on soybean root nodulation in multi-elements contaminated soils. Ecotoxicol Environ Saf 150:62-69. https://doi. org/10.1016/j.ecoenv.2017.12.036

Wang L, Xue C, Nie X, Liu Y, Chen F (2018b) Effects of biochar application on soil potassium dynamics and crop uptake. J Plant Nutr Soil Sci 181:635-643. https://doi.org/10.1002/jpln.20170 0528
Ye L, Zhang J, Zhao J, Luo Z, Tu S, Yin Y (2015) Properties of biochar obtained from pyrolysis of bamboo shoot shell. J Anal Appl Pyrolysis 114:172-178. https://doi.org/10.1016/j. jaap.2015.05.016

Ye J, Joseph SD, Ji M, Nielsen S, Mitchell DRG, Donne S, Horvat J, Wang J, Munroe P, Thomas T (2017) Chemolithotrophic processes in the bacterial communities on the surface of mineral-enriched biochars. ISME J 11:1087-1101. https://doi. org/10.1038/ismej.2016.187

Zhang H, Chen C, Gray EM, Boyd SE, Yang H, Zhang D (2016) Roles of biochar in improving phosphorus availability in soils: a phosphate adsorbent and a source of available phosphorus. Geoderma 276:1-6. https://doi.org/10.1016/j.geoderma.2016.04.020 